\title{
PENGARUH FAKTOR PSIKOLOGIS TERHADAP KEPUTUSAN BERKUNJUNG WISATAWAN MICE MELALUI PT. Y\&R KE BALI
}

\author{
Ni Putu Masni Nistari \\ I Putu Sudana \\ I GPB. Sasrawan Mananda \\ Email : putumasni@ymail.com \\ PS. S1 Industri Perjalanan Wisata \\ Fakultas Pariwisata UNUD
}

\begin{abstract}
Tourism is a global industry sectors and potentially to be developed as a source of government income countries and regions. MICE (Meeting, Incentive, Convention and Exhibition) in Indonesia has great potential and is the flagship product of the tourism industry Indonesia. The purpose of this research is to determine the influence of psychological factors toward MICE tourists visiting decision to Bali through PT. Y\&R.

Sampling technique used in this research is purposive sampling. Samples are 100 respondents and sampling method is accidental sampling. Test instrument used are validity, reliability and test the classical assumption of normality test, multicollinearity, and heteroscedasticity test. Data were analyzed using multiple linear regression analysis.

The results of hypothesis testing psychological factor partially and simultaneously the test and $F$ test is a significant effect and positive value to the decision of MICE tourists visited through PT. Y $\& R$ to Bali. Based on the analysis of multiple test showed that psychological factors have a positive coefficient values consisting of motivation (X1) of 0.216, perception (X2) is 0.298, learning (X3) of 0.370 , beliefs and attitudes (X4) of 0.212 against the decision to visit. Value Adjusted $R$ Square of 0.610 or $61.0 \%$ of decision variables been influenced by psychological factors, while $39.0 \%$ describe by other causes beyond the variables studied.
\end{abstract}

Keywords : The Influence, Decision to Visit, Psychological Factors, MICE.

\section{PENDAHULUAN}

Pariwisata merupakan sektor industri global yang sangat potensial untuk dikembangkan oleh pemerintah sebagai salah satu sumber pendapatan negara maupun daerah. Ahli ekonomi mendefinisikan permintaan sebagai suatu daftar daripada jumlah barang dan jasa apa saja termasuk pariwisata yang mau dan dapat dibeli oleh konsumen pada berbagai harga selama waktu tertentu, (Cooper, 1999). Di Indonesia ada banyak jenis kegiatan wisata. Menurut Pendit (1994), ada beberapa jenis pariwisata berdasarkan motif wisatawan untuk mengunjungi suatu tempat, yaitu wisata budaya, wisata maritim atau bahari, wisata cagar alam atau taman konservasi, wisata pertanian atau agrowisata, wisata buru, wisata wisata MICE akan terus berkembang dari tahun ke tahun. Hal ini dapat dilihat dari trend pertumbuhan tempat atau venue penyelenggaraan wisata $M I C E$ secara terus menerus. Berdasarkan laporan mengenai World Map of Exhibition Venue, telah terjadi peningkatan jumlah ruang pameran exhibition hall sejak tahun 2006 dengan pertumbuhan per tahunnya mencapai sebesar 2,3\% (UFI, Union Des Foires 2011).

Pada era globalisasi ini terutama didukung dengan kemajuan teknologi, pengetahuan serta persaingan bisnis yang menyebabkan banyaknya diselenggarakan berbagai pertemuan, perundingan baik di skala nasional dan internasional, sehingga prospek Industri MICE semakin meyakinkan. Terlebih lagi industri $M I C E$ di tanah air semakin cerah 
Nomor 69/2015 oleh Presiden Joko Widodo tentang bebas Visa kunjungan bagi 45 negara. Pada umumnya industri MICE menciptakan para wisatawan yang datang dengan jumlah besar, lama tinggal lebih lama sehingga jumlah uang yang dibelanjakan lebih banyak serta berdampak pada promosi dan image Indonesia ke dunia internasional selain itu memberikan manfaat langsung pada ekonomi masyarakat seperti hotel, biro perjalanan wisata, usaha kuliner, cinderamata, pramuwisata, hingga transportasi lokal. Hal ini sejalan dengan tujuan kepariwisataan yang terdapat dalam pasal 4 Undang Undang Republik Indonesia No 10 Tahun 2009 Tentang Kepariwisataan.

Perkembangan wisata konvensi pada industri MICE (Meeting, Incentive, Convention and Exibition) di Indonesia memiliki potensi besar dan merupakan salah satu produk unggulan industri pariwisata Indonesia yang tertuang dalam pasal 14 ayat 1 Undang-Undang Republik Indonesia No 10 Tahun 2009 Tentang Kepariwisataan. Sarana akomodasi dan lokasi kegiatan MICE tersebar dibeberapa kawasan pariwisata di Bali. Kawasan Pariwisata tersebut meliputi Kawasan Pariwisata Nusa Dua (termasuk Tanjung Benoa, Nusa Dua dan Jimbaran), Kawasan Pariwisata Sanur, Kawasan Pariwisata Kuta (termasuk Kuta, Legian dan Seminyak) dan Kawasan Pariwisata Ubud.

Mengetahui perilaku konsumen akan berhasil apabila kita dapat memahami aspekaspek psikologis yaitu motivasi, persepsi, pembelajaran serta keyakinan dan sikap manusia secara keseluruhan.

Tabel 1. Jumlah Meeting per Kota-kota di Asia Tenggara Tahun 2011 - 2015

\begin{tabular}{|c|c|c|c|c|c|c|}
\hline Peringkat & Kota & 2011 & 2012 & 2013 & 2014 & 2015 \\
\hline 5 & Singapore & 142 & 150 & 175 & 142 & 156 \\
\hline 21 & Kuala Lumpur & 78 & 69 & 68 & 79 & 73 \\
\hline 26 & Bangkok & 70 & 105 & 93 & 73 & 103 \\
\hline 92 & Bali & 23 & 47 & 55 & 38 & 40 \\
\hline 99 & Manila & 22 & 31 & 28 & 22 & 41 \\
\hline 172 & Jakarta & 12 & 13 & 26 & 19 & 16 \\
\hline 212 & Hanoi & 9 & 16 & 27 & 19 & 18 \\
\hline 345 & Yogyakarta & 5 & 3 & 8 & 10 & 8 \\
\hline
\end{tabular}

Berdasarkan Tabel 1, walaupun ketiga kota utama di Indonesia masih terpaut jauh dari beberapa kota lain di kawasan Asia Tenggara. Akan tetapi hal ini tidak menutup kemungkinan bagi ketiga kota tersebut dan kota-kota lainnya di Indonesia untuk mengembangkan wisata MICE karena Indonesia memiliki potensi yang besar untuk mengembangkan industri MICE. Sebagai negara yang memiliki banyak destinasi wisata, Indonesia dapat menjadi surganya MICE dunia. Untuk itu, pemerintah daerah memiliki peran yang sangat penting dalam upaya mengembangkan wisata MICE di daerah masing-masing dan salah satunya Bali. Wisatawan akan merasa puas jika kebutuhan dan keinginannya dapat terpenuhi, sehingga upaya pemerintah maupun pengelola dalam meningkatkan jumlah kunjungan wisatawan MICE ke Bali dengan menggunakan layanan PT. $Y \& R$ bisa tercapai secara maksimal sesuai dengan target pencapaian pertumbuhan wisatawan.

\begin{abstract}
Penting untuk mengetahui pengaruh faktor psikologis terhadap keputusan berkunjung wisatawan MICE melalui PT. Y\&R ke Bali. Faktor psikologis yang dimaksud adalah motivasi, persepsi, pembelajaran serta kepercayaan dan sikap.
\end{abstract}

\section{METODE PENELITIAN}

PT. Y\&R beralamat di. Jalan Tukad Balian, The Grand Griya Loka Kavling 8, Renon, Denpasar Selatan. Adapun variabel bebas yang digunakan yaitu, motivasi, persepsi, pembelajaran serta keprcayaan dan sikap dan variabel terikatnya yaitu keputusan berkunjung. Variabel yang digunakan dapat dilihat pada tabel berikut. Pada tabel 2 ini digunakan variabel untuk mengukur pengaruh faktor psikologis terhadap keputusan berkunjung wisatawan MICE melalu PT. Y\&R ke Bali.

Jenis data yang digunakan yaitu deskriptif data kuantitatif dengan sumber data primer dan sekunder. Teknik pengumpulan 
kuesioner dan studi kepustakaan. Responden yang dipilih sebanyak 100 dengan teknik pengambilan sample Purposive Sampling dengan metode pengambilan sampel Accidental Sampling. Data yang didapat diolah menggunakan analisis regresi berganda, dihitung menggunakan metode statistik SPSS 17.0 for windows. Dengan proses uji validitas, uji reliabilitas, uji asumsi klasik, pengujian hipotesis menggunakan pengujian simultan (Uji F) dan pengujian parsial (Uji t).

\section{HASIL DAN PEMBAHASAN}

Hasil dari karakteristik responden yang dilakukan terhadap wisatawan MICE melalui PT. Y\&R ke Bali sebanyak 100 orang yaitu sebesar 30\% wisatawan yang datang berumur 31-40 tahun sebanyak $67 \%$ wisatawan lakilaki lebih dominan dan menurut daerah asal wisatawan asal Jakarta paling banyak yaitu $35 \%$ datang ke Bali untuk melakukan kegiata MICE.

Hasil uji validitas sebanyak 20 indikator terhadap variabel-variabel dinyatakan valid karena koefisien korelasi lebih tinggi dari 0,3 dan semakin tinggi koefisien korelasinya semakin tinggi tingkat validitas sebuah item. Hasil uji reliabilitas instrumen penelitian ini dinyataka reliabel sesuai dengan nilai koefisien Cronbach's Alpha yang lebih besar dari 0,7 .

Nilai signifikansi dari residual menunjukkan bahwa besarnya nilai Asymp.Sig (2-tailed) adalah 0,927 dan lebih besar dari 0,05 . Dapat disimpulkan bahwa uji Kolmogrov-Smirno menyatakan bahwa data terdistribusi secara normal.

$$
\text { Hasil uji glejser dari uji }
$$

heterokedastisitas dengan nilai signifikansi variabel independen lebih besar dari 0,05 . Maka dapat disimpulkan bahwa pada model regresi tidak terjadi heterokedastisitas atau model regresi terjadi kesamaan varians dari residual suatu pengamatan ke pengamatan lain.

Pada uji multikolinieritas tidak ada satupun variabel independen yang memiliki nilai Tolerance kurang dari 0,10 nilai Variance Inflation Factor (VIF) ketiga variabel tidak lebih dari 10. Variabel motivasi sebesar 1,52, variabel persepsi sebesar 1,802, variabel pembelajaran sebesar 1,597 dan variabel kepercayaan dan sikap sebesar 1,843. Jadi danat dicimnulkan hahxa tidak teriadi motivasi, persepsi, pembelajaran, kepercayaan dan sikap.

Dari hasil uji analisis regresi berganda diperoleh persamaan regresi $\mathrm{Y}=-1,231+$ $0,216 \mathrm{X} 1+0,298 \mathrm{X} 2+0,370 \mathrm{X} 3+0,212 \mathrm{X} 4$ + e. yang menunjukkan bahwa masing-masing varibael bebas berpengaruh terhadap variabel terikat.

Hasil uji-t untuk H1 diperoleh angka thitung sebesar 3,017 dengan signifikansi sebesar 0,03 . Nilai signifikan untuk variabel motivasi menunjukkan nilai dibawah tingkat signifikan sebesar 0,05 dan nilai t-hitung sebesar 3,017 > t-Tabel sebesar 1,661 yang artinya bahwa $\mathrm{H} 1$ diterima atau adanya pengaruh motivasi terhadap keputusan berkunjung. Dan besarnya pengaruh motivasi secara parsial adalah sebesar 0,216 (positif).

Hasil uji-t untuk $\mathrm{H} 2$ diperoleh angka thitung sebesar 3,015 dengan signifikansi sebesar 0,03 . Nilai signifikan untuk variabel persepsi menunjukkan nilai dibawah tingkat signifikan sebesar 0,05 dan nilai t-hitung sebesar 3,015 > t-Tabel sebesar 1,661 yang artinya bahwa $\mathrm{H} 1$ diterima atau adanya pengaruh persepsi terhadap keputusan berkunjung. Dan besarnya pengaruh persepsi secara parsial adalah sebesar 0,298 (positif).

Hasil uji-t untuk H3 diperoleh angka thitung sebesar 3,612 dengan signifikansi sebesar 0,00 . Nilai signifikan untuk variabel pembelajaran menunjukkan nilai dibawah tingkat signifikan sebesar 0,05 dan nilai thitung sebesar 3,612 > t-Tabel sebesar 1,661 yang artinya bahwa $\mathrm{H} 1$ diterima atau adanya pengaruh pembelajaran terhadap keputusan berkunjung. Dan besarnya pengaruh pembelajaran secara parsial adalah sebesar 0,370 (positif).

Hasil uji-t untuk $\mathrm{H} 4$ diperoleh angka thitung sebesar 2,529 dengan signifikansi sebesar 0,013 . Nilai signifikan untuk variabel kepercayaan dan sikap menunjukkan nilai dibawah tingkat signifikan sebesar 0,05 dan nilai t-hitung sebesar 2,529 > t-Tabel sebesar 1,661 yang artinya bahwa $\mathrm{H} 1$ diterima atau adanya pengaruh kepercayaan dan sikap terhadap keputusan berkunjung. Dan besarnya pengaruh kepercayaan dan sikap secara parsial adalah sebesar 0,212 (positif).

Hasil Uji-F diperoleh F-hitung sebesar 39,633 dengan nilai signifikansi 0,00. Tingkat signifikansi Tabel 4.16 kurang dari 0,05 dan Fhituno sehesar $39632>$ F-Tahel sehesar 7467 
persepsi, pembelajaran, kepercayaan dan sikap berpengaruh simultan terhadap keputusan berkunjung.

Diperoleh hasil bahwa motivasi berpengaruh positif terhadap keputusan berkunjung wisatawan PT. $Y \& R$ ke Bali yang mengartikan bahwa dari keseluruhan indikator motivasi yang digunakan untuk mengukur, wisatawan yang menggunakan layanan PT. $Y \& R$ telah memperoleh pelayanan yang sesuai dengan harapan mereka. Hasil penelitian ini sesuai dengan beberapa hasil penelitian yang telah dilakukan sebelumnya.

Hasil menyatakan bahwa persepsi menjadi faktor psikologis dari wisatawan dalam menetukan keputusan. Persepsi yang baik akan menunjukkan sebuah sikap komitmen yang nantinya akan direflesikan dalam bentuk kepercayaan.

Dinyatakan bahwa pembelajaran merupakan variabel dari faktor psikologis wisatawan yang berbeda beda pada setiap individunya yang menentukan dalam menentukan sebuah keputusan dan sebuah pembelian.

Diperoleh hasil bahwa kepercayaan dan sikap wisatawan berpengaruh positif terhadap keputusan berkunjung wisatawan MICE melalui PT. $Y \& R$ ke Bali yang mengartikan bahwa dari keseluruhan indikator yang digunakan untuk mengukur, wisatawan $M I C E$ yang menggunakan layanan PT. $Y \& R$ telah memperoleh pelayanan sesuai dengan harapan mereka. Hasil penilitian ini sesuai dengan beberapa hasil penelitian yang dilakukan sebelumnya.

Dari hasil yang diperoleh diantara kelima variabel tersebut, keempat variabel bagian dari faktor psikologis yaitu, motivasi, persepsi, pembelajaran, kepercayaan dan sikap berpengaruh terhadap keputusan berkunjung wisatawan.

\section{SIMPULAN DAN SARAN Simpulan}

1. Motivasi (X1) secara parsial berpengaruh positif dan signifikan terhadap keputusan berkunjung.

2. Persepsi (X2) secara parsial berpengaruh positif dan signifikan terhadap keputusan berkunjung

3. Pembelajaran secara parsial berpengaruh positif dan signifikan terhadap keputusan herkuniuno
4. Kepercayaan dan sikap secara parsial berpengaruh positif dan signifikan terhadap keputusan berkunjung.

5. Motivasi (X1), persepsi (X2), pembelajaran (X3), kepercayaan dan sikap (X4) berpengaruh positif dan signifikan secara simultan terhadap keputusan berkunjung.

\section{Saran}

1. Penggunaan variabel independensi faktor psikologis yaitu motivasi, persepsi, pembelajaran serta kepercayaan dan sikap. Diharapkan penelitian selanjutnya dapat menggunakan variabel-variabel lainnya yang mempengaruhi keputusan berkunjung sehingga dapat menghasilkan penelitian lebih bervariasi dan responden untuk penelitian selanjutnya dengan persepsi wisatawan yang lebih bervarian.

2. $\mathrm{PT}$. Y\&R sebagai penyedia layanan $M I C E$ seharusnya membuat promosi yang lebih kreatif lagi mengingat pada variabel pembelajaran terdapat indikator yang bernilai rendah pada kemenarikan promosi daya tarik wisata MICE di Bali.

3. Bagi para stakeholder pariwisata di Bali harus tetap bersama-sama menjaga dan melestarikan daya tarik wisata di Bali agar tetap populer sehingga meningkatkan kunjungan wisatawan MICE yang datang ke Bali dari tahun ke tahun.

\section{DAFTAR PUSTAKA}

Cooper, 1999. Metode Penelitian Bisnis, alih bahasa Widyono Soecipto dan Uka Wikarya, Jilid 11, Jakarta: Erlangga.

Kotler, Philip dan Gary Armstrong. 2001. Prinsip-prinsip Pemasaran, Jilid 1. Edisi Kedelapan. Jakarta: Erlangga.

Pendit, Nyoman S. 1994. Ilmu Pariwisata Sebuah Pengantar Perdana. Jakarta: Pradnya Paramita. 